\title{
ASSESSMENT OF LIFE IN RURAL AREA FROM THE PERSPECTIVE OF A GENDER APPROACH
}

\author{
R.B. Salmorbekova ${ }^{1}$, S.K. Imanbaev ${ }^{2}$, I.B. Karabaeva ${ }^{3}$ \\ ${ }^{1}$ National Academy of Sciences of the Kyrgyz Republic, Bishkek, Kyrgyz Republic, \\ e-mail:r.salmorbekova@mail.ru \\ ${ }^{2}$ Kyrgyz National University J. Balasagyn, Bishkek, Kyrgyz Republic, \\ e-mail:samat_bish@mail.ru \\ ${ }^{3}$ Osh State University, Bishkek, Kyrgyz Republic
}

DOI: $10.14258 /$ ssi(2021)3-02

The work analyzes the social problems of modern life in rural areas of the Kyrgyz Republic. With the help of a sociological survey, the level and quality of life of the rural population have been analyzed. The study covered 14 villages and conducted 18 focus groups. The research reflects social problems in the context of a gender approach and reveals main factors influencing the efficiency of socio-economic development of rural areas. In the course of the research, it was found that many villages were abandoned and slightly lagged in their development. The respondents assessed a good quality of life as good health, earning money in the village, drinking water supply, peace, and tranquility in society, family, etc. Respondents associated low quality of life with a lack of stability in the country; migration and unemployment; financial dependence; misunderstanding in the family, divorce; moral impoverishment (loss of harmony, respect). In general, the quality of life has improved over the past five years: $31.9 \%$ of men and women reported about «significant improvement», and $41.7 \%$ - about «improvement», regardless of age, $26.4 \%$ noted that it remained the same, none of the respondents noted that their living conditions have deteriorated over the past five years. The authors conclude that rural residents have learned the laws of market relations and changed their outlook on life, without demanding anything from the state. The rise in pensions, benefits, teacher salaries, and the rise in livestock prices, especially in recent years, have contributed to an improvement in the quality of life. With the increase in money, the consumption of household goods has increased.

Keywords: states, gender, quality of life, countryside, the standard of living, focus group 


\section{ОЦЕНКА ЖИЗНИ В СЕЛЬСКОЙ МЕСТНОСТИ В РАЗРЕЗЕ ГЕНДЕРНОГО ПОДХОДА}

\section{Р.Б. Салморбекова ${ }^{\text {, }, ~ С . К . ~ И м а н б а е в ~}{ }^{2}$, И.Б. Карабаева ${ }^{3}$}

${ }^{1}$ Национальная академия наук Кььгызской Республики, Бишкек, Кыргызская Республика, e-mail: r.salmorbekova@mail.ru

${ }^{2}$ Кьргызский национальный университет им. Ж. Баласагына, Бишкек, Кыргызская Республика, e-mail: samat_bish@mail.ru

${ }^{3}$ Ошский государственный университет, Бишкек, Кьргызская Республика

Проанализированы социальные проблемы современной жизни в сельской местности Кыргызской Республики. С помощью социологического исследования, охватившего 14 сел (проведено 18 фокус-групп), изучены уровень и качество жизни сельского населения. Основные вопросы исследования отражали социальные проблемы в разрезе гендерного подхода. Проанализированы основные факторы, влияющие на эффективность социально-экономического развития сельской местности. В ходе исследования выявлено, что села отстают в своем развитии. Хорошее качество жизни респондентами оценивалось как хорошее здоровье, возможности зарабатывать деньги в селе, обеспеченность питьевой водой, мир и спокойствие в обществе, семье и т.д. Низкое качество жизни ассоциировалось с отсутствием стабильности в стране; миграцией и безработицей; финансовой зависимостью; непониманием в семье, разводом; моральным обнищанием (потерей гармонии, уважения). В целом качество жизни улучшилось за последние пять лет: $31,9 \%$ мужчин и женщин сообщили о «значительном улучшении», а 41,7\% - о «положительном улучшении», независимо от возраста, 26,4\% отметили, что оно осталось прежним, ни один из респондентов не отметил, что их жилищные условия ухудшились за последние пять лет. Сравнивая ответы, авторы делают вывод о том, что сельские жители изменили свой взгляд на жизнь и перестали ждать помощи от государства. Повышение пенсий, пособий, заработной платы учителей и рост цен на скот, особенно в последние годы, способствовали улучшению качества жизни. С ростом количества денег увеличилось потребление товаров для дома.

Ключевые слова: государство, гендер, качество жизни, сельская местность, уровень жизни, фокус-группа

\section{Introduction}

In the Kyrgyz Republic today, 32 administrative-territorial units have the status of a village. According to the statistics committee, $64 \%$ of the population lives in rural areas, and social problems of the rural population are becoming more and more serious. During the implementation of the agrarian reform, it was planned to create a competitive sector. The socio-economic crisis in rural areas has led to a decrease in funding for existing facilities and programs for the development of the social sphere of the village. In the countryside, there was an increase in social problems, among which the most significant were 
related to the low standards of living of the population. An increase in unemployment, a decrease in the level of culture, difficulties in maintaining a family and children, the uncertainty of a significant part of the rural population in the future, a lack of spiritual ideals and values, leads to a decrease in the cultural level of the rural population.

\section{Methodology}

This study was carried out in 2018-2019 in rural areas; the field study covered 14 villages throughout the republic. The research was fulfilled by the initiative of graduate students to write a dissertation on the problems of the level and quality of life in rural areas. In autumn in the period of October-November 2019, with the help of independent sociologists. 18 focus groups were conducted and 84 respondents participated in individual interviews.

Two methods were used:

1.Discussions with Key Informants (KIs);

2. Focus Group Discussions (FGDs).

Many unresolved problems; in particular, the division of society on a regional basis, the growing problems of the security of the country's citizens also affect the overall situation in the country (Aitiev, Salmorbekova, 2020: 67-71). Today it is not possible to define a single universal measure that would cover all the components and processes that form the quality of life system. Most likely, the function of optimal measurement can be assign to a set of indicators: absolute and relative, qualitative and quantitative, objective and subjective, as well as rating aggregates (Sadyraliev, 2021: 58-66).

\section{Research results}

The people of village are dependent on livestock, own large-size (cows and horses) and small-size livestock (sheep and goats). They send their livestock to the pastures in the summer with the herders and prepare fodder for winter. A key informant said, "Veterinary services are provided at a low level and the villagers cannot cure livestock".

The Pasture Committee regulates the use of pastures and improves the road infrastructure to the pastures. They charge fees from villagers for the pasture use. "Many herders do not know that they are supposed to pay fees".

Most of the village has a mild climate and it has lands between the mountain ridges which is ideal for agriculture. Thus, the inhabitants are engaged in agriculture. The land is very fertile and conducive for growing most crops, especially potatoes. "We have issues with buying oil as it is getting expensive, and we also spend a lot of money for sowing seeds, cultivating land, and collecting harvest". Another key informant added, "We also have problems with selling the agricultural products. Though famous for having good climate for farming. We live in the center of village and we do not have any land for farming". Another key informant added: "You can say that we are like town people, we live here and buy all agricultural products from the market because we do not have land for farming".

\section{Basic services, shops, markets, and transportation}

The key informants were asked if they can reliably access quality basic services such as electricity, water, telephone, and sanitation. 
The inhabitants do not have any issues with the provision of electricity. They also don't have issues with water. Regarding gas, a key informant said, "There is no centralized gas provision and the villagers use gas bottles or electricity for cooking and heating".

The villagers have access to effective cell phone connections. The mobile reception is very good in the village and all mobile companies have their coverage in the village. There is also an internet café and, as one key informant said, "many villagers also have internet access at home".

Each household has its own latrine in the yard. There is a very good centralized service of collecting garbage and each three days the transport comes to collect garbage.

The villagers buy their products for daily consumption from a large number of shops, department stores, privately owned small shops (kamoks) and markets.

The regional center has large markets: livestock, agricultural market, clothing market. Local transport between villages, private cars. Almost $98 \%$ of taxi drivers do not have patents and do not pay taxes for their paid services.

\section{Access to and quality of services}

The health and education services that the villagers use, both formal and informal, were explored, and more specifically how the villagers access these services (including physical access, affordability, any socio-cultural obstacles) and how they perceive the quality of the services they use.

\section{Health services}

Among the medical facilities, there are a district hospital, family health centre, a polyclinic, and a maternity hospital. There are several drug stores in the village. Many inhabitants of other villagers come to get services in these health facilities. Improving the quality of life of the population in Kyrgyzstan is the main goal of the state social policy (Musaeva, Salmorbekova, Rustamova, and Abdullaeva, 2020: 348).

In addition, there are now many commercial health organizations, which sell medicine and promote their business. A FGD participant gave examples of "Sibirskoye zdorovie" and "Tianshi", which work closely with medical doctors so that they attract more customers. One FGD participant also said that some villagers also get treatment from traditional healers (kozu achyktar).

Thus, the inhabitants do not have any problems with access to the health services, but they had a lot to say about the quality of services they get. One FGD participant said that he does not believe the young doctors who are graduating from medical institutions, and he gets health consultations from old doctors (who are not practitioners anymore). Another FGD participant said, "They [medical workers] may refuse you saying that there is no bed [place] at the hospital if you don't offer a bribe" and another participant added, "Doctors treat patients very rudely if you don't give bribe, they will not look at you, and thus you need to find connections". Another respondent said, "I had to undergo surgery recently and I had to get a loan from bank to pay a doctor". Thus, most of the participants of FGD expressed their dissatisfaction with the health services they get in the village. One participant said, "Corruption is very strong in health services, and we need to reduce it". 
Another participant added, "There is health insurance and one can get concessions at the hospital for health services with that insurance. But we still have to purchase all medicine for money from our own pockets. We are forced to give money".

One FGD participant said, "We pay money for the petrol of the ambulance if we call them. Even then they don't come immediately. But we often threaten them saying that we would complain to the chief doctor and only then they come". Another FGD participant also said, "Previously, the medical workers could provide consultations to the pregnant women about how to deliver a child. But there is none these days. The pregnant women are not looked after well these days, and too much formally".

Regarding whether there have been any changes in the provision of health services during the last five years, the FGD participants said the following. One FGD participant said, "The salary of health workers increased, but the quality of their services remained the same". Another FGD participant said, "No change, the corruption still prevails", while another FGD participant also said, "When you come to a doctor with a pain in your stomach, then the doctor asks "What is inside your stomach, a horse or a sheep [hinting on corruption]?". One participant of the FGD on migration also mentioned, "German visits a doctor for prophylactics, Russian goes to see a doctor when he gets sick, but Kyrgyz goes to a doctor when he is dying" (meaning that many Kyrgyz also often bear the sickness and may not visit a doctor until it is late. Thus, many villagers are quite careless of their health and then end up paying more money when they get sick).

\section{Education services}

Educational infrastructure of the regional centre Kochkor, where the study took place, consists of four general education schools and one vocational school. The quality of education in schools in the regional centre is better than in the village, so our FGD participants send their children to study there, even if they live about $4-5 \mathrm{~km}$ from the regional centre. There is no consensus about the quality of teaching and the competency of stuff. One FGD participant believes that older teachers teach better, while another participant disagrees, "now the school curriculum has changed and the old teachers cannot teach this new curriculum".

FGD participants commented on the shortcomings of school education. One of them said, "It would be good if the knowledge of the teachers is also tested while hiring them. We have teachers with poor knowledge". Other FGD participants also agreed, "Good teachers should treat students well", and "a teacher should build good rapport and be able to attract the students. They should teach interesting lessons. We ourselves purchase textbooks". One more FGD participant stated, "Teachers have opened additional courses after lessons, and they do not pay much attention to their lessons, instead they focus more on those paid courses where they can make more money. They charge 250 som (\$4) for an additional lesson. But the children do not want to sit hungry and study after school hours to attend the additional classes". Poor facilities of the school, lack of school equipment's and textbooks are also negatively affecting education quality. Two kids are using one textbook", and mentioned, "It is very cold in classrooms in winter. If the desks are warm, then the children's health is also good". Another FGD participant also reported about the practices 
of the teachers who organize events during holidays at the school and instruct their students to bring food from home.

Regarding the changes during last five years, the FGD participants observed the following. "The teachers are now asking for more gifts with higher prices when their students graduate from the school [a practice that exists from the Soviet times, when graduating class of students give presents to their teachers]. Observed that children nowadays are more serious towards their education and many students want to study abroad, and thinks that children's knowledge is quite high these days.

FGD participants also shared their ideas about higher education. One of them said, "Our children apply to universities in Bishkek, but not Naryn. My daughter studied in China for one year after Grade 9 and now she is a student at Bishkek Humanities University". One more FGD participant observed, "Nowadays, the one who has more wealth can afford studying at universities, and those who are poorer are studying at vocational schools".

Similar to the inhabitants of other villages, the people send their daughters to get higher education. But a FGD participant said, "The girls are not provided with hostel in Bishkek because they think we are quite close to the city". Another FGD participant also added, "They come back with higher education diplomas, but they cannot find jobs according to their profession. There are competitions for job places, but there is corruption there". One more FGD participant said, "Many young people do not come back because there are no jobs in the village. Many of them go to business or trade, and there are many young people with two diplomas who are now working in the market [as traders]". One FGD participant observed, "There are too many universities and their quality is really low, and it would be good to reduce the number of them and increase the quality".

The participants of youth FGDs responded that it is difficult to enter universities these days. One young girl said, "Universities education quality is also not good. Some people are just buying university diplomas". Another young girl disagreed, "It all depends on the person himself. If someone wants to really study hard, then he can get education in any university. There are people who study on their own without giving money, but those students do not study hard and then they are obliged to give money". Some young girls and boys also mentioned that it has become more difficult to enter universities because tuition fees at universities have increased. One young boy said, "It is more difficult to enter university because contract fees increased. The lowest is 32,000 som (\$376) per year".

\section{Social relations and issues of social cohesion Gender and generation}

Studied gender roles and relationships, as well as how the relationship between parents and children can change in recent years. At home, the women are engaged in cooking, keeping house clean, doing laundry and looking after children. The men work mostly in the yard. They also assist women by fetching water home, cutting wood, and heating home in winter by making fire in oven. A female participant of FGD said, "Many women work in such professions as teachers, doctors, finance people, at kindergarten, and in markets. The women predominate in such workplaces as schools, health organizations, and kindergartens. Many men work in police forces, tax inspection, and other government offices". Another female 
FGD participant added, "Men mostly work in agricultural farms and animal husbandry. The farmers grow potato and carrots. Many men also engage in trading because of joblessness". A male FGD participant commented, "In spring and autumn, the women also work in potato fields. Some young women and girls also work for paid labor collecting potato and they are paid 600 som (6-7 \$) per day”. Despite the fact that monetary incomes and living standards in the city are higher than in the countryside, urban dwellers have much more problems with adequate nutrition than rural dwellers (Erkinbekov, 2010: 35).

Both female and male FGDs participants observed that it is the women who mostly work at home, however, the participation of men in the household work increased recently. A participant of female FGD said, "Men have started participating more actively in the household work during last 20 years" and another female participant commented, "During last 3-4 years, younger men have started more actively participating in looking after small children at home. The men also assist their wives more with household work, such as cutting wood and so on". A male FGD participant agreed, "Men assist their wives with work at home. They bring water from another street, because our street doesn't have water. Men also fire coal for heating in ovens".

Men or women discuss and make joint decisions on how to spend the family profits from farming and livestock husbandry. A female FGD participant said, "We always consult each other when spending money, for example, for purchasing coal, or for children's needs". A male FGD participant said, "Women keep all the money at home, and they are like bank in the family". Another male FGD participant added, "Women can spend the money they earn, but they inform their husbands on how they spend money". Another male FGD participant commented, "The Kyrgyz have a saying, have consultation with your rib, thus, we discuss all the time with our wives".

Men and women can both be legal owners of property (e.g. house). Every member of the family gets their shares of land, including the female members. A female FGD participant said, "Though the legal owners of the property are often men in the family", while a male FGD participant opposed, "Woman can also have legal right for house or land". Gender plays a role in the developmental process from early childhood onwards and constitutes a "culture" that is socially shared and affects all aspects of an individual's life: social roles, sexual expression, belief system, interests, and occupations, among others (Gavray, and Boulard, 2021: 786).

At village level, both men and women participate, but as one female participant said, "If a woman works at public office, then she is more active in the village level issues. A housewife mostly sits at home". A male FGD participant agreed, "Women are quite active these days. Many women are doing government jobs. Once upon a time there was a matriarchy and we are moving in that direction now".

Both men and women want their children get higher education. A male FGD participant said, "We treat our sons and daughters equally, and we try to send all of them to get higher education". A female FGD participant mentioned that some parents cannot send their children to universities if they do not have good wealth. She said, "Those parents who don't have money are not educating their children even though their children may have good knowledge". A male FGD participant added, "Contract fees are high so many young 
men cannot get education even though they may have good knowledge". Another male participant said, "What is good of having university education when there are people who are working in the market with two university diplomas".

The older male and female FGD participants recognize that there are differences between the older and younger people of the village. A male FGD participant mentioned, "Nowadays young people are really patriots. Many young people of 16-17 years old died on April 7th, 2010 for the future of the country". Another male participant added, "They are more gifted. They are serious in terms of their life goals and many of them speak many foreign languages. They speak English and know how to use computers". A female FGD participant commented, "Old generation want to stick to the old ideology, while the young people want changes". Another female FGD participant said, "Young people do not pay serious attention to traditions and culture, but old people also people do not understand what young people know".

The young people in village want to live separately from their parents after they get married. A male FGD participant said that parents continue helping their sons even after they start living separately. Children also help their parents with money or by building or renovating their house. Parents often help their children by looking after their grandchildren.

Older FGDs participants also mentioned that young people are affect by negative influences of drinking alcohol and smoking. One male participant said, "There are many shops and all of them have alcohol, and because of joblessness, the young people drink alcohol. Kyrgyzstan is producing $50 \mathrm{mln}$ tons of alcohol, and people are consuming it".

Young girls and boys shared during the FGDs that their participating in family decisions increased. One girl said, "The more you grow, you can participate in decisions more actively. Before we would do everything, our parents told us, but now we share our views as well". One girl said, "Whoever is sick, he or she makes a decision himself or herself about treatment. In animal husbandry, the role of men is more". Another girl said, "I decide myself about getting higher education". Another girl also said, "Girls make decision about higher education, but in consultation with their parents". Boys also agreed, but they also said that the parents still make most of the family decisions. One boy said, "Parents also decide about farming and other matters, and until you start living separately the parents make decision".

Young boys and girls also mentioned about differences between older and younger generations. A girl said, "Yes, sometimes our views are different. For example, they don't want to allow us to go to disco". Another girl said, "I met one young man and we had good relations, but then when I introduced him to my parents, but my mother was against him. They did not like my choice. Thus, I did not disobey my parents and I had to break up with that young man". A young boy said, "My elder brother also did not want that I enter higher education. He wanted that I stayed home to help with construction but I disagreed".

Young boys and girls often do not participate in the village life actively because they are very busy. One girl said, "I haven't heard of any group and organization for youth. Women have their group on handicraft named Golden Hand. But mostly older women work there. Young people are too busy and they do not participate in village activities". 
The social relations amongst the resident's village are friendly. The villagers know each other and they help each other during family events such as weddings and funerals. The villagers also participate actively in communal events as well as in the traditional system of reciprocal labour sharing called ashar. Relatives and close friends especially participate in ashar. A 25-year old man said, "When my relatives build a house, I go and help in laying foundations".

Men mostly do hard manual labour in ashar such as constructing a house, gathering fodder or collecting harvest. Women assist in construction by cooking during ashar. Women actively participate in ashar when they make carpet. The 12 individual interviewees know about reciprocal labour sharing ashar, and most of them actively participate in ashar.

The villagers also help close relatives, friends and neighbours when they have large family events such as weddings or funerals. A 52-year old man said, "I help my friends when they have guests for their large family occasions, they also help me by offering their labour". A 36-year old woman added, "Men do work outside home, while women do work inside home during those functions". A 52-year old man said, "During family events, relatives, friends and neighbours come to help. Men slaughter animal, cut wood, cook meat, and boil water for tea, while women help inside house by washing dishes, setting table-cloth, pouring tea for guests".

The individual interviewees also mentioned that they participate in cleaning the public spaces with the help of ashar. A 52-year old man said, "We clean the surroundings with ashar especially in spring". A 24-year old school teacher also mentioned that teachers and students participate in cleaning of the school surroundings with ashar.

A 51-year old woman also mentioned that the villagers have yraja (community contributions) by collecting money when someone has a wedding or funeral or sherine when a smaller group of friends or neighbours collect money by rotating. She said that the villagers may collect 1,000 to 10,000 ( $\$ 11$ to $\$ 1100$ ) soms depending on their capacity. She plays sherine with her friends by collecting 1,000 som each member.

The individual interviewees also responded to the question whether the relations of the villagers have changed one way or another during last five years. A 52-year old man said, "The villagers' relations have changed for the last five years. Everyone is working for the sake of their own families and there is a hidden competition between the villagers. Young people are joining bad activities because of material interest (theft, money laundering)". A 38-year man also believes that the villagers' relation has changed. He said, "Everyone is trying to improve their own life. At the same time, there are many negative things in life, for example, I notice more disputes because of water shortage or land shortage". On the contrary, a 36-year old woman believes that the relations of the villagers have improved, because the number of people who drink alcohol is decreasing. Two younger respondents said that the relations of the people remain the same as before, and sometimes they are less friendly towards each other. Key informants also agreed that the relations of the villagers have changed and mostly not for the good side. One key informant said, "Yes, the relations have changed, but not for the good. People have become more aggressive". Another key informant said, "Before the people had virtues of socialism, honesty, well manners, but now the people do not have them, and thus, the relations are not good". 
Therefore, governance processes should be regarded as a means towards social transformation and, in particular, towards the transformation of social systems of gender roles. This form of democratic governance would be expressed through institutional changes or, in other words, through changes of the rules and regulations, which organize the relationships among the different actors or partners in different settings, especially those relationships between the state and civil society, and those established among the state, market and family. In this sense, changes would open up new opportunities to transform gender roles assessing the implications of public policies for both men and women. This would include legislation and policies in all areas and levels (Pérez-Jorge, Domínguez, de la Rosa Hormiga, Martín, and Morales, 2015: 154).

\section{Conclusion}

According to the research results, $80.5 \%$ as a whole rated the quality of life as "good" $72.2 \%$, "excellent" $-8.3 \%, 18 \%$ have "satisfactory or average, neither good nor bad". According to our observations, $40 \%$ of respondents aged 18-25 rated their quality of life as "good", and 32\% of respondents over 25 to 40 years old rated it as "better", over 40 years old $-28 \%$ "excellent". The quality of life interpretation includes the following categories: health; peace in the family and society; provision of clean drinking water; life without credit and education.

The respondents rated the following categories as low quality of life: poor health; lack of stability in the country; unemployment; financial debt; misunderstanding in the family, divorce; moral impoverishment (loss of harmony, respect). Thus, none of the respondents noted that their living conditions have deteriorated over the past five years. According to the research results, such a strong imbalance in gender is not noticeable. Men and women in all spheres of life have equal rights, did not reveal discrimination in gender-age relations. Because the population learned the laws of market relations and changed their outlook on life, without demanding anything from the state.

\section{БИБЛИОГРАФИЧЕСКИЙ СПИСОК}

Айтиев Ш., Салморбекова Р.Б. Социально-экономические последствия смены политического режима в Кыргызстане. Социальная политика и социальное партнерство, 2020, No. 7, 67-71.

Садыралиев Ж. С. Сопоставление понятий уровня и качества жизни: субъективное наполнение. Society and Security Insights, 2021, No. 1, 58-66.

Уровень жизни населения Кыргызской Республики. 2015-2019 гг. Бишкек, 2019.

Эркинбеков Т.Ж. Региональные особенности социального неравенства в Кыргызстане. Бишкек, 2010.

Gavray C., Boulard, A. Depressive Mood and Violent Behaviour among Teenagers: A Gender Dynamic Approach to the Study of Stressor Effects. Psychology, 2021, No. 12, 785-804. doi: 10.4236/psych.2021.125048

Musaeva A., Salmorbekova R., Rustamova D., Abdullaeva Z. Social Qualimetry of Public 
Services Standardization in the Kyrgyz Republic. Advances in Applied Sociology, 2020, No. 10, 348-355. doi: 10.4236/aasoci.2020.109021

Pérez-Jorge D., Domínguez Y., de la Rosa Hormiga M., Martín L., Morales M. Governance in the Field of Public and Gender Policies. Sociology Mind, 2015, No. 5, 153-161. doi: $10.4236 / \mathrm{sm} .2015 .53014$

\section{REFERENCES}

Ajtiev, Sh., Salmorbekova, R.B. (2020). Social'no-ekonomicheskie posledstviya smeny politicheskogo rezhima $\mathrm{v}$ Kyrgyzstane [Socio-economic consequences of changing the political regime in Kyrgyzstan]. Social Policy and Social Partnership, no. 7, 67-71.

Sadyraliev, Zh.S. (2021). Sopostavlenie ponyatij urovnya i kachestva zhizni: sub"ektivnoe napolnenie [Comparison of the concepts of the level and quality of life: subjective content]. Society and Security Insights, no. 1, 58-66.

Uroven' zhizni naseleniya Kyrgyzskoj Respubliki. 2015-2019 gg. (2019) [The standard of living of the population of the Kyrgyz Republic in 2015-2019]. Bishkek.

Erkinbekov, T.Zh. (2010). Regional'nye osobennosti social'nogo neravenstva v Kyrgyzstane [Regional features of social inequality in Kyrgyzstan]. Biskek.

Gavray, C. and Boulard, A. (2021). Depressive Mood and Violent Behaviour among Teenagers: A Gender Dynamic Approach to the Study of Stressor Effects. Psychology, no. 12, 785-804. doi: 10.4236/psych.2021.125048

Musaeva, A., Salmorbekova, R., Rustamova, D. and Abdullaeva, Z. (2020). Social Qualimetry of Public Services Standardization in the Kyrgyz Republic. Advances in Applied Sociology, no. 10, 348-355. doi: 10.4236/aasoci.2020.109021

Pérez-Jorge, D., Domínguez, Y., de la Rosa Hormiga, M., Martín, L. and Morales, M. (2015). Governance in the Field of Public and Gender Policies. Sociology Mind, no. 5, 153-161. doi: $10.4236 / \mathrm{sm} .2015 .53014$ 